\title{
Conservation of Southern Ocean Islands: invertebrates as exemplars
}

\author{
Steven L. Chown · Jennifer E. Lee • \\ Justine D. Shaw
}

Received: 5 December 2007 / Accepted: 22 January 2008/Published online: 12 March 2008

(C) Springer Science+Business Media B.V. 2008

\begin{abstract}
The Southern Ocean Islands (SOI) have an exceptionally high conservation status, and human activity on the islands is low by comparison with more tropical islands. In consequence, overexploitation, pollution and habitat destruction have had little influence on the invertebrate biotas of the islands, although overexploitation of pelagic species has the potential for an indirect influence via reduction of nutrient inputs to the terrestrial systems. By contrast, invasive alien species, the local effects of global climate change, and interactions between them are having large impacts on invertebrate populations and, as a consequence, on ecosystem functioning. Climate change is not only having direct impacts on indigenous invertebrates, but also seems to be promoting the ease of establishment of new alien invertebrate species. It is also contributing to population increases of invertebrate alien species already on the islands, sometimes with pronounced negative consequences for indigenous species and ecosystem functioning. Moreover, alien plants and mammals are also affecting indigenous invertebrate populations, often with climate change expected to exacerbate the impacts. Although the conservation requirements are reasonably well-understood for terrestrial systems, knowledge of freshwater and marine near-shore systems is inadequate. Nonetheless, what is known for terrestrial, freshwater and marine systems suggests that ongoing conservation of SOI invertebrates requires intervention from the highest political levels internationally, to slow climate change, to local
\end{abstract}

S. L. Chown $(\bowtie) \cdot$ J. E. Lee $\cdot$ J. D. Shaw

Department of Botany and Zoology, Centre for Invasion

Biology, Stellenbosch University, Private Bag X1,

Matieland 7602, South Africa

e-mail: slchown@sun.ac.za improvements of quarantine measures to reduce the rates and impacts of biological invasions.

Keywords Global change-type drought . Indirect interactions - Insect conservation . Marine invasions $\cdot$ Rodents

\section{Introduction}

Between $30^{\circ}$ and $60^{\circ}$ latitude the northern and southern hemispheres differ substantially. In the north, land and water constitute approximately the same surface area. In the south, the land:water ratio is a mere 1:15 (Chown et al. 2004). The vast Southern Ocean dominates this part of the globe. New Zealand, Patagonia and small parts of Australia and Africa comprise the majority of the land. However, within and on either side of the Antarctic Polar Frontal Zone (an area separating two high speed regions of the Antarctic Circumpolar Current, the sub-Antarctic Front to the north and the Antarctic Polar Front to the south) a small number of archipelagos makes up the remainder of the terrestrial area. These are the Southern Ocean Islands (SOI) (Fig. 1).

Given their occurrence right around the Southern Ocean, the islands differ considerably in their geological histories, past and current glacial extents, current climates and vegetation (Table 1). Whilst some of the islands, such as Prince Edward Island, are entirely volcanic, young $(<500,000$ years), and show no signs of glaciation at the height of the last glacial maximum (LGM), others have a more complex geology and history. Macquarie Island constitutes a raised section of seafloor (Selkirk et al. 1990). The Kerguelen Islands (a large archipelago) are still partly glaciated, and have a complex history associated with the 
Fig. 1 Schematic map of the position of the Southern Ocean Islands, which straddle the Antarctic Polar Frontal Zone. In this review we have excluded the Maritime Antarctic islands such as Bouvetøya, and the South Orkney, South Shetland and South Sandwich islands (see Chown and Convey 2006, 2007 for additional information)

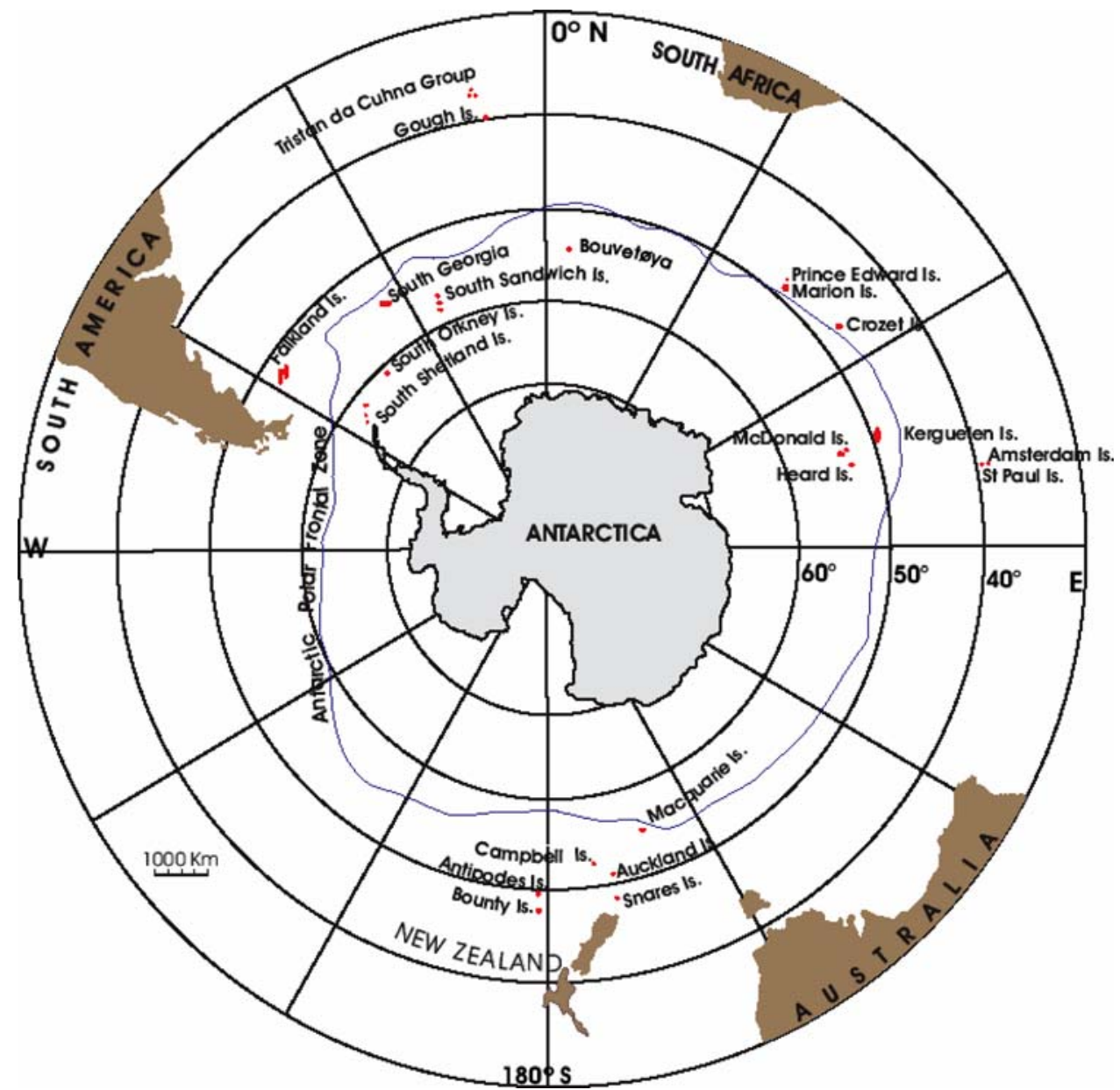

$100 \mathrm{ma}$ (million years) geological evolution of the large igneous province of the Kerguelen Plateau, of which some parts were sub-aerial (i.e. above sea level) at least as far back as 93 ma and consistently for at least $40 \mathrm{ma}$ (Hall 2002; Wallace et al. 2002). The geological history of the Crozet archipelago remains something of a conundrum (Craig 2003).

In terms of climates, similar variation can be found, from the temperate, warmer islands, such as Gough Island and the Auckland Islands, to the north of the Polar Frontal Zone, to the much colder islands south of the zone, such as South Georgia and Heard Island. The islands also differ in the extent to which they are influenced by frontal weather, and in some cases the considerable height of the islands means that the climates on the weather and lee sides of the islands are wholly different (see le Roux 2008 for recent discussion). Nonetheless, the majority of the SOI have highly oceanic climates, and the climates of those islands lying within or to the south of the Polar Frontal Zone are showing a strong warming, and often drying trend in step with global climate change (Bergstrom and Chown 1999; Convey 2006; le Roux and McGeoch 2007).
Given this range of locations, histories and climates, the vegetation also shows marked dissimilarity among the SOI (Fig. 2). For example, Heard Island (53 ${ }^{\circ} \mathrm{S}$ ) has only 12 vascular plant species and closed vegetation communities only in coastal areas and in some deglaciated valleys (Scott and Bergstrom 2006). Above approximately $50 \mathrm{~m}$ in elevation, vegetation is open, and above about $200 \mathrm{~m}$ comprises cryptogams only. From about $300 \mathrm{~m}$ (depending on position and aspect) the slopes are almost entirely icecovered. By contrast, Gough Island $\left(40^{\circ} \mathrm{S}\right)$ supports 70 species of vascular plants, including trees (Phylica arborea, Sophora macnabiana) and tree ferns (Blechnum palmiforme) at lower elevations, but above ca. $300 \mathrm{~m}$ comprises mostly wet heath and moorland vegetation (Wace 1961; Hänel et al. 2005). Similarly, a structurally complex flora can be found at the Auckland Islands (Anonymous 1997), whereas at South Georgia, closed vegetation is mostly restricted to the lowlands (LewisSmith and Walton 1975). Whilst differences in the structure of the vascular flora amongst islands are clear, at the majority of islands bryophytes dominate in terms of species richness and have considerable, though perhaps somewhat 
Table 1 Location, area, elevation, age, mean annual sea surface temperature, and number of introduced plants and insects on the Southern Ocean Islands (adapted from Chown et al. 1998)

\begin{tabular}{|c|c|c|c|c|c|c|c|}
\hline Island & $\begin{array}{l}\text { Position } \\
\text { (Decimal degrees) }\end{array}$ & Area $\left(\mathrm{km}^{2}\right)$ & Altitude (m) & Age (ma) & $\operatorname{SST}\left({ }^{\circ} \mathrm{C}\right)$ & $\begin{array}{l}\text { Alien Vascular } \\
\text { plants }\end{array}$ & $\begin{array}{l}\text { Alien } \\
\text { insects }\end{array}$ \\
\hline West Falkland & $51.5 \mathrm{~S}, 60.5 \mathrm{~W}$ & 3,500 & 701 & 2,500 & 7.67 & 66 & 5 \\
\hline East Falkland & $51.5 \mathrm{~S}, 58.5 \mathrm{~W}$ & 5,000 & 705 & 2,500 & 7.29 & 78 & 22 \\
\hline South Georgia & $54.25 \mathrm{~S}, 37.0 \mathrm{~W}$ & 3,755 & 2,950 & 120 & 1.49 & 53 & 8 \\
\hline Tristan da Cunha & $37.1 \mathrm{~S}, 12.25 \mathrm{~W}$ & 86 & 2,060 & 1 & 15.32 & 93 & 37 \\
\hline Nightingale & $37.42 \mathrm{~S}, 12.5 \mathrm{~W}$ & 4 & 400 & 18 & 15.32 & 6 & 4 \\
\hline Inaccessible & $37.25 \mathrm{~S}, 12.75 \mathrm{~W}$ & 12 & 600 & 6 & 15.32 & 20 & 12 \\
\hline Gough & $40.33 \mathrm{~S}, 9.54 \mathrm{~W}$ & 57 & 910 & 6 & 12.35 & 24 & 71 \\
\hline Marion & $46.9 \mathrm{~S}, 36.75 \mathrm{E}$ & 290 & 1,230 & 0.45 & 5.53 & 17 & 18 \\
\hline Prince Edward & $46.63 \mathrm{~S}, 37.95 \mathrm{E}$ & 44 & 672 & 0.21 & 5.59 & 3 & 3 \\
\hline Cochons & $46.1 \mathrm{~S}, 50.23 \mathrm{E}$ & 70 & 775 & 0.4 & 4.87 & 6 & 3 \\
\hline Apôtres & $45.97 \mathrm{~S}, 50.43 \mathrm{E}$ & 3 & 289 & 5.5 & 5.11 & 2 & 0 \\
\hline Pinguoins & $46.5 \mathrm{~S}, 50.4 \mathrm{E}$ & 3.16 & 360 & 1.1 & 4.87 & 1 & 0 \\
\hline Est & $46.43 \mathrm{~S}, 52.2 \mathrm{E}$ & 130 & 1,090 & 8.75 & 4.75 & 5 & 2 \\
\hline Possession & $46.42 \mathrm{~S}, 51.63 \mathrm{E}$ & 150 & 934 & 8.1 & 4.78 & 101 & 7 \\
\hline Kerguelen & $49.37 \mathrm{~S}, 69.5 \mathrm{E}$ & 7,200 & 1,840 & 95 & 3.46 & 36 & 13 \\
\hline Heard & $53.1 \mathrm{~S}, 73.5 \mathrm{E}$ & 368 & 2,745 & 40 & 1.74 & 1 & 1 \\
\hline McDonald & $53.03 \mathrm{~S}, 72.6 \mathrm{E}$ & 2.6 & 230 & 0.079 & 1.85 & 0 & 0 \\
\hline Amsterdam & $37.83 \mathrm{~S}, 77.52 \mathrm{E}$ & 55 & 881 & 0.7 & 15.17 & 81 & 18 \\
\hline St Paul & $38.72 \mathrm{~S}, 77.53 \mathrm{E}$ & 8.1 & 268 & 0.5 & 14.59 & 10 & 9 \\
\hline Macquarie & $54.62 \mathrm{~S}, 158.9 \mathrm{E}$ & 128 & 433 & 0.7 & 5.13 & 5 & 5 \\
\hline Snares & $48.12 \mathrm{~S}, 166.6 \mathrm{E}$ & 3.28 & 152 & 120 & 10.95 & 2 & 8 \\
\hline Auckland & $50.83 \mathrm{~S}, 166.0 \mathrm{E}$ & 626 & 668 & 18 & 9.22 & 33 & 10 \\
\hline Campbell & $52.5 \mathrm{~S}, 169.17 \mathrm{E}$ & 113 & 567 & 16 & 7.83 & 88 & 19 \\
\hline Antipodes & $49.68 \mathrm{~S}, 178.77 \mathrm{E}$ & 21 & 366 & 0.5 & 7.9 & 2 & 13 \\
\hline Bounty & $47.72 \mathrm{~S}, 179.0 \mathrm{E}$ & 1.35 & 89 & 189 & 9.63 & 0 & 0 \\
\hline
\end{tabular}

unappreciated, roles to play in the terrestrial systems, especially at higher elevations (see e.g. Bergstrom and Selkirk 1997; Gremmen and Smith 2008).

\section{Patterns and mechanisms: historical and ecological biogeography}

As might be expected, the different geological histories of the SOI have contributed to the identity of the biotas living on them, with the degree of influence of isolation and history depending to some extent on the dispersal abilities of the taxa involved: mobile species such as seabirds are less influenced by large ocean barriers than sedentary species such as insects (Chown 1994; Muñoz et al. 2004; Greve et al. 2005; Chown and Convey 2007). For these reasons, the historical biogeography of the region has been the subject of much contention, with claims both for and against Udvardy's (1987) proposal for a single biogeographic province, 'Insulantarctica', including most of the islands (reviewed in Greve et al. 2005; Chown and Convey
2006). Recent, nestedness and phylogeographic analyses have begun to resolve the areas of contention, showing that an 'either/or' argument for 'Insulantarctica' is too simplistic and ignores important among-taxon variation (e.g. Greve et al. 2005; Stevens et al. 2006). In consequence, much remains to be done to clarify the historical biogeography of the region. Phylogenetic and phylogeographic studies, especially of the arthropods, are likely to help do so in the near future (see e.g. Allegrucci et al. 2006; Grobler et al. 2006; Myburgh et al. 2007).

Taking a more ecological perspective, early work identified glacial extent during the LGM, isolation and persistently low temperatures as the major factors influencing among-SOI variation in the species richness of arthropods and vascular plants (e.g. Gressitt 1970; Abbott 1974; Chown 1990a). More recent work (Chown et al. 1998, 2005) has shown that elements of both classic island biogeography theory (isolation and available area), and the influence of varying energy availability (measured as sea surface temperature) explain variation in richness of terrestrial vascular plants (see Table 1) in keeping with 

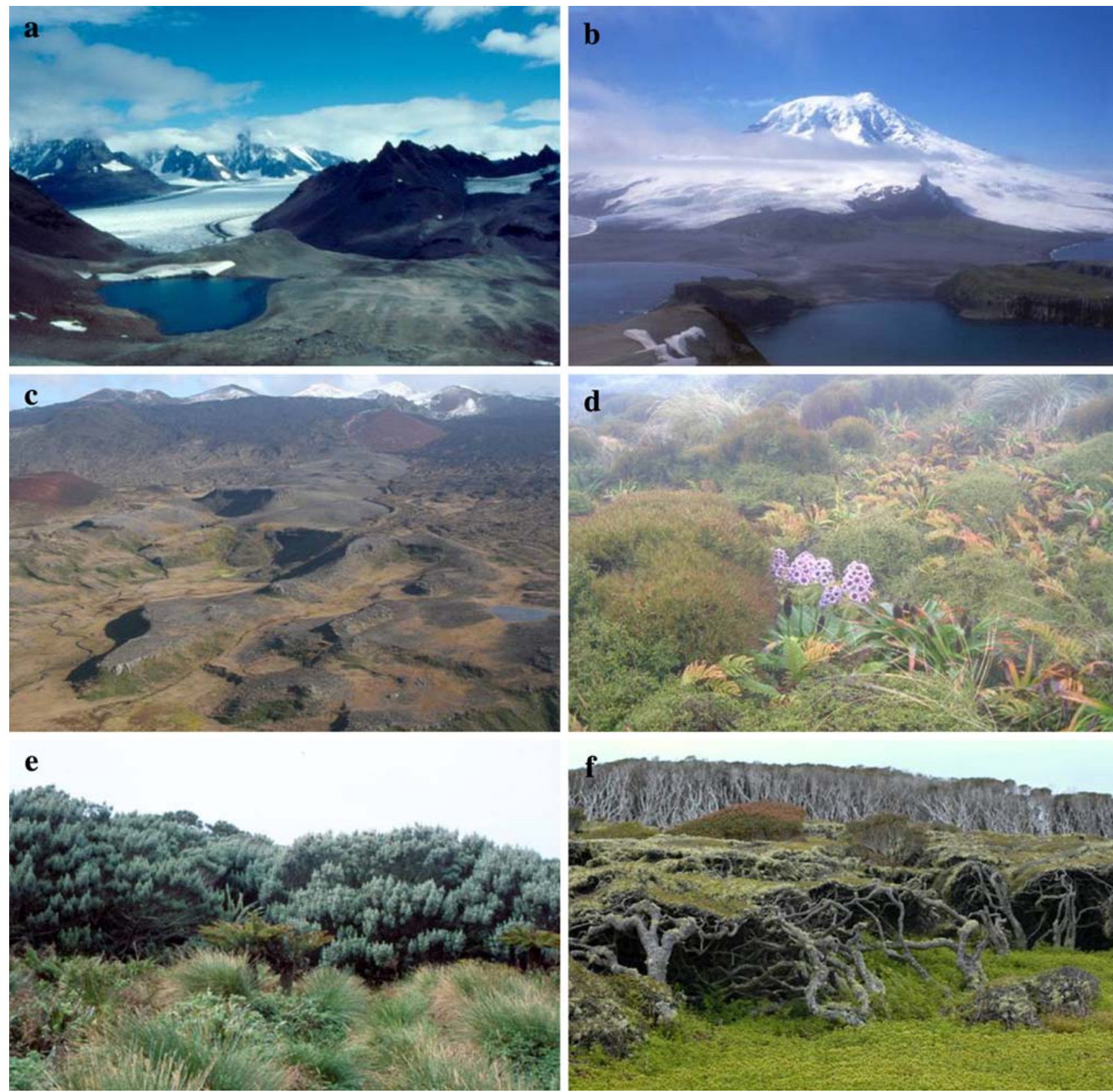

Fig. 2 Vegetation differs profoundly within and across the Southern Ocean Islands, as a consequence of elevation, manuring effects, exposure, and water availability. These images illustrate the variety of landforms and vegetation types found on the islands. (a) Fellfield above the Neumeyer glacier on South Georgia; (b) Atlas Cove area of Heard Island showing volcanic sand and a small altitudinal range in vegetation; (c) Tafelberg at Marion Island showing mire (yellow),

species-energy theory (reviews in Gaston 2000; Hawkins et al. 2003; Evans et al. 2004). The situation is more complex for the indigenous insects (Table 1). Depending on the analysis (i.e. including/excluding spatial autocorrelation), distance to the closest continent, indigenous plant richness, area, and sea surface temperature (SST-a fernbrake (green) and fellfield (grey) areas; two scoria cones are visible in the middle distance; (d) Lowland vegetation on Campbell Island with Pleurophyllum speciosum flowering in the foreground; (e) Phylica arborea in fernbush at Gough Island; (f) a rata (Metrosideros umbellata) thicket on Enderby Island, Auckland Islands. Image (d) was taken by Brent Sinclair, the remainder by the authors

surrogate for mean annual land surface temperature) are all correlates of richness (Chown et al. 1998, 2005). Clearly, dispersal capabilities of the insects and isolation of the islands have been significant in influencing the richness patterns (Greve et al. 2005) and energy is likely to have influenced richness via the mechanisms usually proposed, 
such as increasing numbers of individuals reducing extinction rates of the rarest species and therefore elevating richness (Evans et al. 2004). However, the role of indigenous plant species richness in influencing insect species richness is more controversial. More generally, it has long been maintained that plant richness might have a substantial influence on herbivore richness (e.g. Gaston 1992; Siemann et al. 1998). However, this idea is contentious, with some studies arguing that evidence in favour of a relationship between plant and herbivore richness is perhaps weaker than was once thought, at least at large spatial scales (Hawkins and Porter 2003; Hawkins and Pausas 2004, but see also Novotný et al. 2006). For the SOI it is difficult to determine the nature of the relationship between vascular plant and insect richness. Whilst indigenous plant richness is a strong correlate of insect richness (irrespective of analytical approach), one spatially explicit approach suggests that this is a consequence of similar responses of both groups to island area (Selmi and Boulinier 2001), whilst another does not support this assertion (Chown et al. 2005). Irrespective, the modern analyses demonstrate that in terms of richness variation among islands, SOI plants and insects follow patterns expected from oceanic islands (see Kalmar and Currie 2006). That is, large, high energy, less-isolated islands have the highest richness of insect and plant taxa. Unfortunately, how diversity in the other components of the arthropod fauna (such as spiders, mites and springtails) varies, and what mechanisms might underlie this variation, are not well known, largely as a consequence of poor sampling across all islands in the region (see Pugh 1993, 2004; Pugh and Scott 2002; Pugh et al. 2002 for recent invertebrate faunal catalogues).

\section{Conservation status of the islands}

Because the SOI provide the only terrestrial ecosystems at mid- to high southern latitudes across much of the southern hemisphere (Bergstrom and Chown 1999), their conservation value has long been recognized (reviewed in Dingwall 1995; see also Chown et al. 2001; Bergstrom and Selkirk 2007). The island groups discussed here are governed by five different nations: United Kingdom, South Africa, Australia, New Zealand, and France. Unlike Antarctica (which is governed under the Antarctic Treaty System), no international agreements or treaties apply specifically to the Southern Ocean Islands. However, more general international agreements to which the above states are party, such as the Convention on Biodiversity, and the Agreement for the Conservation of Albatrosses and Petrels do apply to the islands (Hull and Bergstrom 2006; Chown et al. 2006). Nonetheless, most of the islands enjoy a high conservation status (de Villiers et al. 2006). The five New Zealand sub-
Antarctic island groups (Snares, Bounty, Antipodes, Auckland, and Campbell islands), Heard and McDonald Islands, Gough Island and Macquarie Island are all World Heritage Areas (at the highest IUCN Reserve Status of Category Ia). Several other island groups in the region are also clearly eligible for World Heritage status (Chown et al. 2001), and a nomination for the Prince Edward Islands has been submitted. Macquarie Island is listed as a UNESCO Biosphere Reserve.

At a National level, the New Zealand sub-Antarctic islands are all National Nature Reserves. Macquarie Island and Heard and McDonald Islands (Australia) have the highest reservation status, Nature Reserve and Commonwealth Reserve, respectively, under their governing legislations (State and Federal). Marion and Prince Edward Island (South Africa) are classified as a Special Nature Reserve under South African legislation (National Environmental Management: Protected Areas Act) (Davies et al. 2007). South Georgia has National status (United Kingdom) as a Protected Area, and the Kerguelen and Crozet Islands (France) and Gough Island (United Kingdom) are all National Nature Reserves (de Villiers et al. 2006).

The frequency and intensity of human activity varies across the SOI. At present many of the SOI are visited annually by scientific expeditions (comprising scientists and support staff), and have research and/or meteorological bases occupied throughout the year. The annual number of semi-permanent occupants ranges from 0 to 100 (de Villiers et al. 2006). Unlike most of the islands, the Falkland Islands and Tristan da Cunha archipelago have permanent human settlements and a much more complex set of governance and conservation arrangements.

Tourist vessels visit many of the islands. However, no tourists are allowed to land on the Prince Edward Islands, the Antipodes, Bounty, Snares, Inaccessible or Gough islands. Visits to all other islands require permits that place restrictions on operators, but these vary among the different islands (de Villiers et al. 2006). Permits limit the number of visits per season, number of visitors permitted ashore at once, vessel capacity, number of landing sites, nights ashore, and/or time ashore, and often specify procedures for decontamination prior to shore transfers (such as bootwashing). South Georgia receives the most tourist visitors in a year (5,427 passengers in 2005/2006) (Frenot et al. 2005; de Villiers et al. 2006).

\section{Conservation threats}

The Millennium Ecosystem Assessment (MA, 2005) identified habitat transformation, overexploitation, climate change, biological invasion and pollution (including $\mathrm{N}$ and $\mathrm{P}$ nutrient loading) as the most significant modern drivers 
of biodiversity loss. For the SOI, habitat transformation and pollution are largely unimportant, and the effects of overexploitation indirect. Habitat transformation is significant only at the permanently inhabited Falkland and Tristan da Cunha islands, and pollution is important in the sense that large-scale acidification of the oceans and the long lifespan of many persistent organic pollutants are having affects around the globe (see e.g. Finizio et al. 1998; Lawton 2007). Likewise, overexploitation of terrestrial organisms is negligible. However, because pelagic species (especially seabirds) contribute large quantities of nutrients to terrestrial systems (e.g. Smith and Froneman 2008), overexploitation in marine systems might have an indirect effect on terrestrial system functioning if seabird populations are severely reduced. Of much more direct significance at the majority of the islands are the effects of biological invasions and climate change, and their interactions.

\section{Climate change}

As we have already noted, temperatures are rising at many of the SOI in step with global climate change, and in many cases rainfall is declining (Bergstrom and Chown 1999). The extent of the change in climate varies among islands as might be expected from their diverse geographic locations. For example, the rate of warming over the last 50 years has been slower at Gough Island than at Marion Island (Jones et al. 2003a; Smith 2002). Moreover, climate change is often more subtle than a simple increase in temperature and decline in rainfall might suggest. For example, at Marion Island, the increase in temperature is being accompanied by more clear-sky evenings, leading to an increase in the number and intensity of freeze-thaw cycles (Smith and Steenkamp 1990; Smith 2002). Counter-intuitively, a warming trend is being accompanied by increases in the number of stressful freezing events. It is these subtleties, as well as the general trends, that have important consequences for invertebrate faunas.

To date, few studies have documented direct impacts of changing climates on the indigenous invertebrate faunas of the SOI. Rather, most investigations have either examined the physiological tolerances of particular species and predicted what might be the outcomes of further change, or have used field experiments to determine what the impact of ongoing warming and/or drying might be. In the former case, much work on Marion Island has suggested that warming and drying are unlikely to compromise many indigenous insect species, at least based on data showing considerable desiccation resistance in several species and high critical thermal maxima in others (e.g. Klok and Chown 1997, 2003; Slabber and Chown 2005). However, two investigations suggest that absolute limits are unlikely to provide a complete picture of the effects of changing climates. First, an investigation of egg development rates has demonstrated pronounced thermal sensitivity in the endemic springtail subspecies (probably a species-see Stevens et al. 2006), Cryptopygus antarcticus travei, to the extent that egg development does not proceed above $15^{\circ} \mathrm{C}$ (Janion et al. unpublished data). Another study demonstrated considerable sensitivity of a keystone species, Pringleophaga marioni (Tineidae), the caterpillars of which are responsible for promoting nutrient release on the island (Smith and Steenkamp 1992), to repeated low temperature exposures. Increasing freeze-thaw cycles associated with increasing numbers of clear-sky evenings as climates change are likely to have negative consequences for this species (Sinclair and Chown 2005). Later work also demonstrated that wandering albatrosses act as thermal ecosystem engineers for the caterpillars, by promoting survival as a consequence of temperature elevation in the albatross nests (which are occupied for ca. 12 months) where caterpillar densities are high (Sinclair and Chown 2006).

Open-top chamber, temperature elevation trials on the Falkland Islands (Bokhorst 2007) and rain-out shelter trials on Marion Island (McGeoch et al. 2006) have both demonstrated complex responses of the soil arthropod fauna to either warming, or warming and drying, depending on the higher taxon in question. For example, at Marion Island, a drying and warming treatment resulted in a much steeper decline in springtail abundance than in the abundance of mites relative to control sites, but even within these groups responses were individualistic at the species level. Thus, the response to climate change will likely not be a change in the relative positions of present communities or assemblages across the island, but rather re-arrangement of species into wholly novel assemblages (McGeoch et al. 2006). Moreover, the trials also revealed that indigenous and introduced species show different responses to experimental warming and drying treatments. Indeed, the interaction between climate change and invasion is one of the most significant threats to the invertebrates of the SOI islands (see below).

\section{Biological invasions}

Southern Ocean Islands are climatically and physically isolated from the surrounding continental landmasses, and have comparatively low human visitation compared with many continental sites (Chown et al. 1998). To a large extent these factors have hindered the establishment of alien species (see Pyšek et al. 2004 for definitions-which include those introduced by humans to one area that have migrated to a nearby one). Although alien species richness is relatively low, it varies substantially among the islands 
(Frenot et al. 2005). Some islands, such as McDonald Island, are pristine with no established alien species, whilst others are highly invaded. For example, of the 99 insect species recorded on Gough Island, 71 are established introductions (Gaston et al. 2003).

Intrinsically, introductions are related to human movements. In the case of the SOI, human visits began in the late 1600 s, but increased in frequency on many islands from the 1800s with the development of whaling and sealing. In recent years, scientific research and tourist operations have become the dominant form of human activity in the region (Frenot et al. 2005). Whilst contemporary human movements and activities are subject to strict controls to prevent the establishment of non-indigenous species (de Villiers et al. 2006), historical activities were not regulated and this likely led to considerable propagule pressure on occupied islands. Indeed, among the strongest predictors of the numbers of established alien species (plants, insects, birds and mammals) across the SOI are numbers of human occupants per year and energy availability (Chown et al. 2005). Moreover, the historical lack of controls has meant that many of the alien species that established early on have had considerable time to become established and in some cases to shape contemporary island assemblages (Chapuis et al. 1994; Frenot et al. 2005; Greenslade et al. 2007a). In this regard, it is important that a clear distinction be drawn between alien species that have established, but are effectively having little or no impact, and those that are transforming entire ecosystems (see Richardson et al. 2000).

Given their profound influences on invertebrate species and ecosystem functioning, it is the invasive alien species that form the focus of the remainder of this review. We use several case studies to illustrate the effects of invasive species on the invertebrates and ecosystems of the SOI. In some instances, alien invertebrate species are having a substantial impact on other invertebrate species or on system functioning. In other cases introduced mammal or plant species are having an impact on invertebrates, or an interaction between mammals/plants and an invertebrate invader is responsible for the impacts. Finally, we show how climate change is not only exacerbating the impacts of invasive alien species already present on the islands, but also how it seems to be enhancing the ability of new species to establish (see also Frenot et al. 2005).

\section{Invasive alien species and their impacts}

\section{Establishment and impact}

No island system is static. Rather, islands are characterized by extinction, colonization and evolution. Isolated islands, such as the SOI, typically have low natural colonization rates (Carlquist 1974). However, human activities have substantially changed the natural levels of immigration. For example, it has been estimated that for Gough Island, background rates of colonization were ca. one species every 1,000 years. Now the rate is one species every 4 years (Gaston et al. 2003). Although increased propagule pressure (see Lockwood et al. 2005 for an overview) is undoubtedly part of the reason for the increase in colonization rates over background levels, it also seems likely that the ease of establishment of invertebrates must also be at least partly responsible. Several studies have demonstrated that despite large population sizes, introduced invertebrate species are often characterized by little genetic variation (e.g. Ernsting et al. 1995a; Greenslade et al. 2007b; Myburgh et al. 2007; Lee et al. 2007), suggesting that only one or a few individuals founded the population. Moreover, it has long been argued that parthenogenesis is a trait promoting establishment on these islands so accounting for a relatively high proportion of parthenogenetic species in the introduced insect fauna (Crafford et al. 1986; Hullé et al. 2003; Jones et al. 2003b).

Irrespective, whether the rates of successful colonization are increasing since human occupation of the SOI is much more difficult to establish because repeated, careful surveys have typically not been undertaken on a regular basis at the islands. At Marion Island, this has been done since the mid1980s and over the past 20 years five new invertebrate colonizations have been documented (Table 2). The

Table 2 Invertebrates that have established at Marion Island since regular surveys commenced in the early 1980s (data from Lee et al. 2007)

\begin{tabular}{lll}
\hline Species & Year established & Reference \\
\hline Plutella xylostella (Lepidoptera, Plutellidae) & $\sim 1986$ & Crafford et al. (1986) \\
Calliphora vicina (Diptera, Calliphoridae) & $\sim 1988$ & Chown and Language (1994) \\
Agrotis ipsilon (Lepidoptera, Noctuidae) & $\sim 1997$ & Hänel et al. (1998), Chown et al. (2008) \\
Aphidius matricariae (Hymenoptera, Braconidae) & $\sim 2001-2003$ & Lee et al. (2007) \\
Porcellio scaber (Crustacea, Porcellionidae) & $\sim 2001$ & Slabber and Chown (2002) \\
\hline
\end{tabular}

Lee et al. (2007) suggested that Trichoplusia orichalcea (Noctuidae) might have become established, but no larvae have been found 
population sizes and infrequency of recording of Calliphora vicina (Calliphoridae) and Agrotis ipsilon (Noctuidae) suggest that neither species might establish permanently. However, both are exceptionally successful elsewhere. A large population of the fly is established at the Kerguelen Islands (Chevrier et al. 1997). Be that as it may, the data are too sparse to detect any trends, though it is noteworthy that three of the species have established despite the adoption of the strict quarantine procedures at the island, in keeping with a predicted increase in the ease of establishment of introduced species as climates ameliorate in the region (Kennedy 1995; Frenot et al. 2005). Strong relationships between energy availability and alien insect richness (Chown et al. 1998, 2005), the restriction of introduced species to low elevations (Gabriel et al. 2001; Hullé et al. 2003), and the clear demonstration that the increase of temperature above a threshold value enabled establishment of $C$. vicina at the Kerguelen Islands (Frenot et al. 2005), provide additional evidence in favour of the prediction. Of course, establishment in no way necessarily means profound impacts on the recipient system. However, several species are now having a considerable influence on terrestrial systems or on other invertebrates.

In 1997, two species of introduced flatworm were found on Macquarie Island (Greenslade et al. 2007b). The more narrowly distributed Arthurdendyus vegrandis (Geoplanidae) apparently feeds solely on earthworms. Of the six terrestrial species of earthworm on Macquarie Island, including those living above the high water mark according to Greenslade (2006), four species are regarded as alien, one endemic and one unknown, and all are at least potential prey for the flatworm. The wider ranging Kontikia andersoni (Geoplanidae) likely feeds on a range of arthropods, annelids and molluscs. Given that relatively few macroinvertebrate predators occur on Macquarie Island (two flatworm, three spider and six staphylinid beetle species), the continuing range expansion of two predatory flatworms has the potential to exert a profound influence on invertebrate populations at the island. Substantial impacts by introduced invertebrate predators have been documented on other islands, most notably by an introduced carabid beetle species Trechisibus antarcticus on indigenous perimylopid beetles on South Georgia (Ernsting 1993; Ernsting et al. 1999; see also below), and by another introduced carabid Oopterus soledaninus on populations of indigenous invertebrates at the Kerguelen Islands (Chevrier et al. 1997).

Slugs have been introduced to several SOI (Pugh and Scott 2002), and are likely to have significant effects on system functioning. Deroceras panormitanum was first documented at Marion Island in the 1970s (Smith 1992). It has since become widespread and abundant, owing partly to helicopter-assisted transport (slugs adhere to wooden packing cases moved by helicopter) around the island (Smith 1992; Chown et al. 2002). Nutrient cycling in the terrestrial system is mostly through a detritus chain dominated by caterpillars of the indigenous flightless moth $P$. marioni, and by several weevil species (Smith and Steenkamp 1992). However, slugs also release prodigious quantities of nutrients as a consequence of their grazing, but do so such that nutrient release relative to carbon release differs considerably from that of the indigenous species. In consequence, different carbon:nutrient ratios are found in the decomposing substrate, with downstream effects on primary production (Smith 2007).

A final example concerns increases in food web complexity. At most of the isolated SOI, especially the more southerly islands, parasitism is uncommon, with only a few parasitoid species known. Often these are restricted to the littoral zone, parasitizing small kelp flies (e.g. Crafford et al. 1986). Recently, a wasp parasitoid, Aphidius matricariae, of an introduced aphid (Rhopalosiphum padi), was discovered on Marion Island (Lee et al. 2007). Although the species does utilize an introduced host, the occurrence of both species has added a level of complexity previously missing from vegetated areas on the island (Chown 1990a).

Invasive plants, mammals and invertebrates

Although the relationship between plants and insects is widely acknowledged, few studies have examined these relationships in detail for invasive species of insects (but see Hulle et al. 2003), and fewer still for the impacts of introduced plant species on invertebrate assemblages. One exception is the effects of dense stands of the grass Agrostis stolonifera on springtails and mites at Marion Island. Typically, mite abundances are higher and springtail abundances unaffected in the invaded sites relative to the control areas (Gremmen et al. 1998). A more complex interaction between invasive grasses, introduced reindeer (Rangifer tarandus) and an introduced predatory beetle and indigenous prey beetle species has been documented for South Georgia (Chown and Block 1997). The introduced predatory carabid, Trechisibus antarcticus, appears to be selecting for larger body sizes in the indigenous prey perimylopid Hydromedion sparsutum owing to considerable predation pressure (Ernsting et al. 1995b, 1999). However, in those areas where reindeer graze most frequently, size is smaller in $H$. sparsutum adults than where reindeer are absent. In the former areas, reindeer promote the spread of the grazing-intolerant invasive grass Poa annua (and in some circumstances the somewhat less tolerant indigenous Festuca contracta). Despite substantial ingestion of these grasses, $H$. sparsustum larvae grow poorly on them by comparison with other, less grazing-tolerant indigenous species. In consequence, by promoting the spread of the 
invasive Poa апnиа, reindeer appear to be selecting indirectly for reduced body size in $H$. sparsutum, whilst selection in the opposite direction is being imposed by the introduced carabid (Chown and Block 1997).

At Macquarie Island, rabbits are likely to be affecting invertebrate populations indirectly by altering vegetation communities (in some cases leading to total denudation). Investigations of invertebrate assemblages has revealed that Stilbocarpa polaris (Apiaceae)-dominated herbfields have the highest invertebrate densities, followed by Poa foliosa (Poaceae)-dominated tall tussock grasslands and Pleurophyllum hookeri (Asteraceae) herbfields (Greenslade 2006), and that among the species most common in these habitats are several indigenous to Macquarie Island (Davies and Melbourne 1999; Greenslade 2006). Recently, the population of introduced rabbits on Macquarie Island has greatly increased, despite early control success (Scott and Kirkpatrick 2008). This increase has been attributed to the complex interactions of several factors including eradication of feral cats in 2000, and resistance to the myxoma virus that was introduced to the island in the 1970s. Rabbits particularly favour the tussock grasses $(P$. foliosa) and large-leaved megaherbs (S. polaris and P. hookeri) (Copson and Whinam 1998). In the last 7 years, drastic changes in vegetation cover across the island have taken place. In many areas herbfields and tall tussock grasslands have been entirely removed due to intense grazing (Scott and Kirkpatrick 2008) (Fig. 3). In addition, large areas of leaf litter and soil have been reworked by rabbit digging and subsequent (or incidental) erosion. Given the apparent preference of invertebrates for the herbfield and tussock habitats, it is likely that substantial change to invertebrate populations has been effected, although this change has yet to be investigated thoroughly.

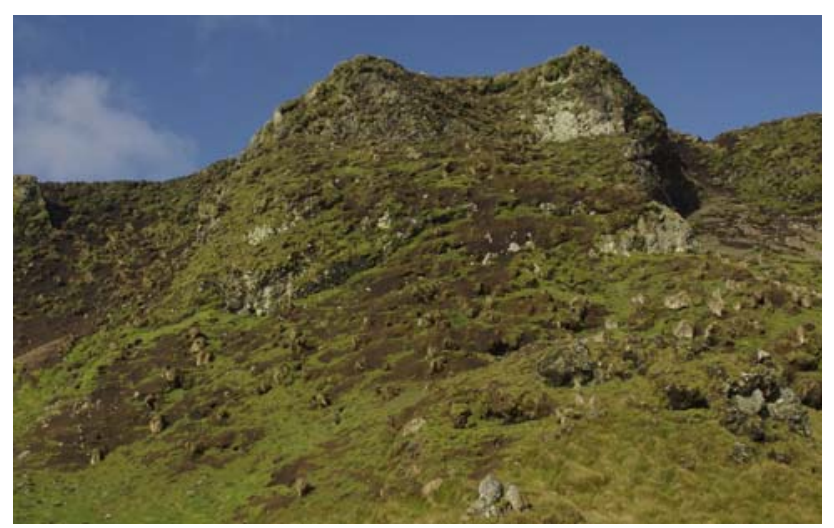

Fig. 3 Rabbit-induced vegetation damage on Macquarie Island. Since the eradication of cats and likely also as a consequence of changing climates and reduced efficacy of Myxoma virus, rabbit numbers have increased over the past 5 years (Scott and Kirkpatrick 2008), with effects on vegetation and likely on invertebrate assemblages
The effects of introduced mammals are often more direct. Introduced rodents, especially house mice, are having pronounced direct effects on invertebrate (particularly insect) populations on several islands, including Gough (Jones et al. 2003c), Kerguelen (Le Roux et al. 2002), Macquarie (Copson 1986) and Marion (Crafford and Scholtz 1987; Smith et al. 2002) islands. At Marion Island, mice have not only led to substantial declines in populations of their preferred prey (Crafford and Scholtz 1987; Chown et al. 2002), but have also altered ecosystem functioning. By reducing populations of the flightless moth, whose caterpillars are keystone species for nutrient recycling (Smith and Steenkamp 1992), mice have had profound effects on nutrient cycling, plant growth and possibly peat formation (Smith and Steenkamp 1990). Moreover, because caterpillars constitute an important component of the diet of overwintering lesser sheathbills (an indigenous, plover-like bird), populations of these species are also declining (Huyser et al. 2000). In addition, by virtue of their size-selective feeding (Fig. 4), mice are not only changing the size distributions of the weevils on Marion Island (but not on nearby, mouse-free Prince Edward Island, Chown and Smith 1993), but may also have caused introgression of two weevil species that probably speciated sympatrically via size-based, positive-assortative mating (Chown 1990b; Grobler et al. 2006).

Invasions and climate change

As we have noted, several studies have predicted increasing ease of establishment of non-indigenous species as climates on the SOI islands change and as the frequency of human

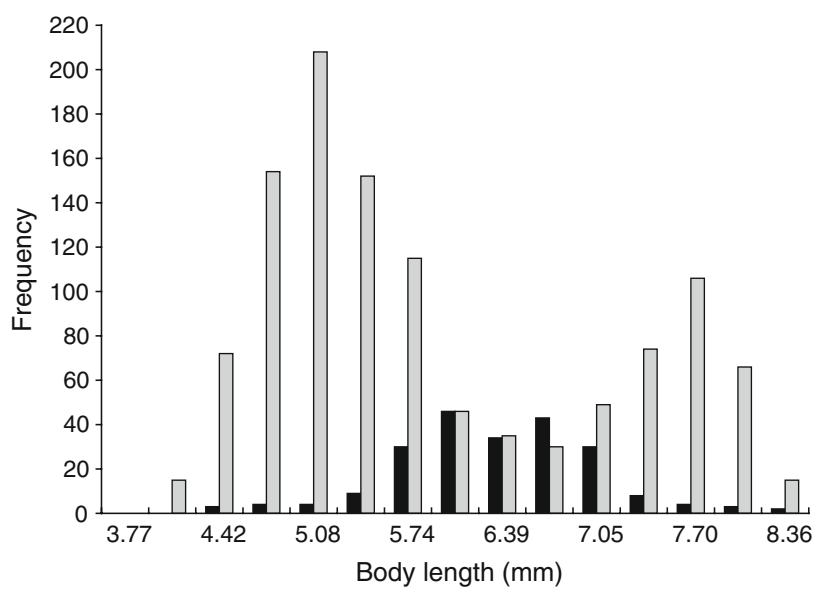

Fig. 4 Frequency distribution of body lengths of two Ectemnorhinus weevil species as recorded in 1986/7 on the cushion plant Azorella selago on Marion Island (grey bars), with mouse, beetle-size preferences indicated in black bars, which have been estimated from body lengths from prey remains in mouse scats (data from Chown and Smith 1993). It appears that the weevil species have now introgressed (Grobler et al. 2006) 
visits increases (see above). However, changing climates are likely also to have direct effects on species already present on the islands in several ways, with important consequences for ecosystem structure and functioning. Physiological data on absolute thermal tolerances and on the relationships between development rate and temperature suggest that not only are the alien species at the island frequently more thermally tolerant than their indigenous counterparts (e.g. Slabber et al. 2007), but also that in response to increasing temperatures, steeper rate-development relationships will mean faster development for alien than indigenous species (Barendse and Chown 2000). For these reasons, and because many of the indigenous species have longer life-cycles (1 year or more) and those of the alien species (Chown et al. 2002), it is expected that the alien species (many of which are invasive-see e.g. Gabriel et al. 2001) will be at an advantage relative to their indigenous counterparts.

Other work has suggested that as a consequence of greater low temperature tolerance, indigenous species are able to occupy higher elevations than alien species (e.g. Gabriel et al. 2001; Slabber et al. 2007), and might possibly have been displaced at lower elevations by large populations of thermally responsive, fast growing invasive species (Jones et al. 2003a, b; Convey et al. 1999; Chown et al. 2002). Increasing temperature may therefore enable invasive alien species to occupy ever higher elevations, with likely detrimental consequences for indigenous species and possibly also for ecosystem functioning. However, the picture may also be much more complicated. For example, currently, the invasive alien slug Deroceras panormitanum is restricted to elevations below ca. $250 \mathrm{~m}$ (Fig. 5) on Marion Island as a consequence of its inability to tolerate temperatures below its freezing point (ca. $-3.3^{\circ} \mathrm{C}$ ) (Lee et al. unpublished data). Whilst a warming trend in mean temperatures might suggest that the slug will

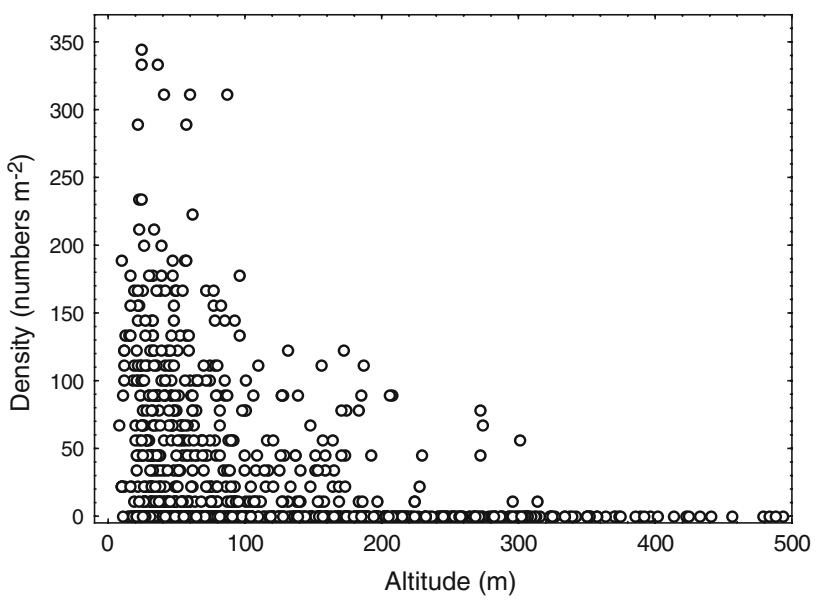

Fig. 5 Densities of the invasive alien slug Deroceras panormitanum on Marion Island. Note the rapid decline in maximum density with elevation (Lee et al. unpublished data) colonize higher elevations (vascular plants on which it feeds extend to at least $600 \mathrm{~m}$-Gremmen 1981), with concomitant effects on nutrient cycling, warming is also being accompanied by larger numbers of freeze-thaw cycles. These might, in fact, further constrain the distribution of the slug on the island.

The combination of warming, drying and differential responses to desiccation of indigenous and invasive species constitute a further way in which global climate change will affect the invertebrates of the SOI. Global change type-drought of the kind forecast for many temperate systems (e.g. Easterling et al. 2000; Breshears et al. 2005) is typical also of several SOI (Bergstrom and Chown 1999). On Marion Island, a combination of laboratory studies and field experiments has shown how global change-type drought will likely tip the balance in favour of invasive over indigenous springtails (Chown et al. 2007). In response to thermal acclimation, the magnitude of phenotypic plasticity in the survival of dry $(75 \%$ relative humidity) conditions does not differ between indigenous and invasive springtails. Rather, the invasive species have longer survival times (at 5 and at $15^{\circ} \mathrm{C}$ ) following acclimation to $15^{\circ} \mathrm{C}$, whilst in the indigenous species, the opposite is found (Fig. 6). Field experiments have revealed that in response to a year of dry and slightly warmer conditions, simulated by rain-out shelters (McGeoch et al. 2006, see also le Roux et al. 2005), the indigenous species declined substantially in abundance, whilst the invasive species showed no change (Fig. 6). The combined laboratory and field trials, and data on the distribution of springtails on Marion Island demonstrating the preference of invasive species for lowland areas, suggest that ongoing change of the type forecast for the island (le Roux and McGeoch 2007) will favour the invasive species. What remains to be determined is the extent to which interactions among the indigenous and invasive springtail species will result in displacement of the indigenous species as has been suggested for South Georgia (Convey et al. 1999).

\section{Conclusions and prospectus}

At first glance, much seems to be known about the terrestrial invertebrates of the SOI and the ways in which climate change and biological invasions are likely to affect their populations and the ecosystems they form part of. However, the information is spatially autocorrelated. Some islands, such as Marion Island, Macquarie Island, and the Kerguelen Islands are comparatively well investigated. By contrast, for others the invertebrate faunas remain poorly surveyed (e.g. mites on most island groups, springtails on many), and little is known about system functioning. Even for reasonably well-investigated islands, information is 
Fig. 6 Survival of dry conditions $(75 \%$ relative humidity) following acclimation to $5^{\circ} \mathrm{C}$ or to $15^{\circ} \mathrm{C}$ by (a) an invasive and (b) an indigenous springtail species from Marion Island at test temperatures of $5^{\circ} \mathrm{C}$ (solid line) and $15^{\circ} \mathrm{C}$ (dashed line). Note that the invasive species performs better following the high temperature acclimation treatment than after the low temperature one. In (c) the responses of springtails to experimental warming and drying are shown as

proportional abundance relative to controls. Note the decline in abundance of the indigenous Redrawn from Chown et al. (2007). Species as follows: Cryptopygus antarcticus, Cryptopygus dubius, Isotoma marionensis, Isotomurus cf. palustris, Pogonognathellus flavescens, Tullbergia bisetosa species (marked with asterisks).
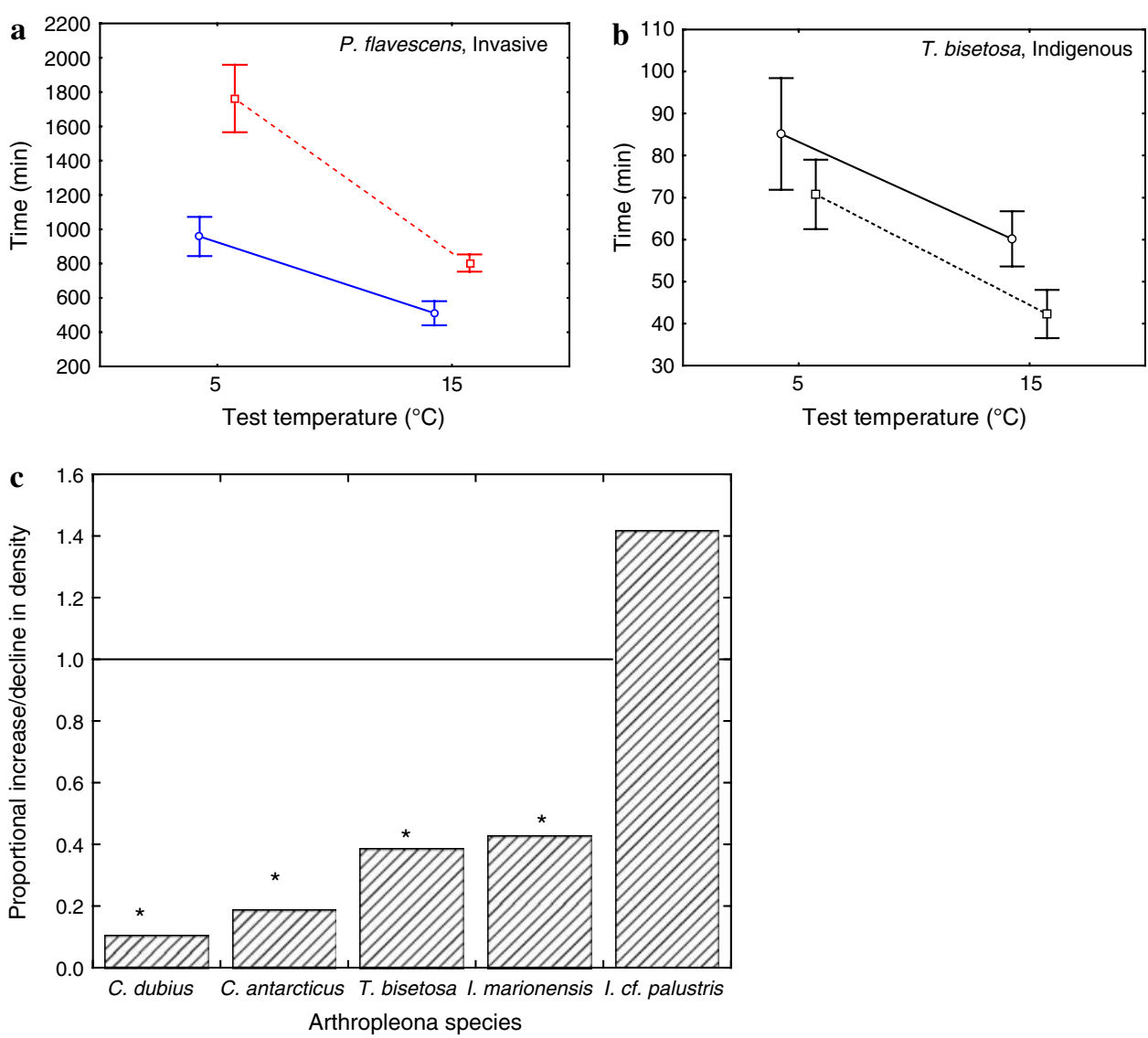

inadequate for systems other than the terrestrial. For example, what the effect of climate change will be on freshwater systems is poorly known, although it is thought that the life history of the South Georgian water beetle Lancestes angusticollis will be affected (Arnold and Convey 1998). How warming will influence interactions between freshwater crustaceans and their food resources is unknown. Similarly, the effects of introduced fish on aquatic invertebrates has not been investigated (Frenot et al. 2005), even though it is well known that these species have considerable impacts on invertebrates elsewhere. For marine systems, the picture is likewise patchy. Recent work has demonstrated that ships, smaller marine craft, and plastic debris can act as vectors for non-indigenous species in the region (Lewis et al. 2003, 2006; Barnes et al. 2006), and that species invasive in other parts of the world, regularly travel to and survive conditions throughout the Southern Ocean (Lee and Chown 2007). However, the extent of introductions to marine systems, and how these species, and those indigenous to a given area, might respond to climate change is far from clear. Southerly species living in cold, polar water might be especially sensitive to rising temperatures given their present intolerance of even relatively small acute changes therein (Peck et al. 2006), but the extent to which responses might evolve or to which plasticity might be re-expressed is only now being studied (Seebacher et al. 2005).

These gaps in current information demonstrate that much remains to be done to document and to understand the mechanisms underlying variation in the invertebrate biotas of the SOI. Moreover, they also show that comprehension of the impacts of climate change and invasion, the two major conservation threats to the SOI, is far from fully developed. Nonetheless, an overview of the work available quickly reveals that sufficient information exists for clear initial recommendations to be made concerning mitigation: International agreements to limit climate change globally require more active political and societal engagement, regional quarantine procedures starting at source (i.e. continental departure points) must be tightened to limit further introductions, better surveys are required locally for early detection of new introductions so that eradication can be implemented, and greater attention should be given to managing increasing human use interests in the region. Whilst the ongoing development of protected areas in the Southern Ocean (including large Marine Protected Areas, Lombard et al. 2007) is encouraging, increasing marine exploitation with potential knock-on effects on systems dependent on nutrient inputs from the sea (e.g. Smith and Froneman 2008) is worrying. So too is the fact that 
dwindling fossil fuel and mineral resources globally will mean increasing consideration of previously uneconomic extractions from ocean plateaus and the seabed. The Southern Ocean Islands will not escape attention as convenient support platforms for such activities. However, it is abundantly obvious that, as some of the most pristine systems on earth, representing habitats unique to the planet, the Southern Ocean Islands have a much greater future value as conservation areas than as convenient staging posts for short-term exploitation of a limited resource base.

Acknowledgments We thank Tim New for inviting this contribution, and two anonymous reviewers for their helpful comments. Our work on Southern Ocean Islands is supported by the Centre for Invasion Biology and by NRF Grant SNA2007042400003 to S.L. Chown.

\section{References}

Abbott I (1974) Number of plant, insect and land bird species on nineteen remote islands in the Southern Hemisphere. Biol J Linn Soc 6:143-152

Allegrucci G, Carchini G, Todisco V, Convey P, Sbordoni V (2006) A molecular phylogeny of Antarctic Chironomidae and its implications for biogeographical history. Polar Biol 29:320-326

Anonymous (1997) Subantarctic Islands heritage. Nomination of the New Zealand Subantarctic Islands by the Government of New Zealand for inclusion in the world heritage list. Department of Conservation, Wellington

Arnold RJ, Convey P (1998) The life history of the diving beetle, Lancetes angusticollis (Curtis) (Coleoptera: Dytiscidae), on subAntarctic South Georgia. Polar Biol 20:153-160

Barendse J, Chown SL (2000) The biology of Bothrometopus elongatus (Coleoptera, Curculionidae) in a mid-altitude fellfield on sub-Antarctic Marion Island. Polar Biol 23:346-351

Barnes DKA, Hodgson DA, Convey P, Allen CS, Clarke A (2006) Incursion and excursion of Antarctic biota: past, present and future. Glob Ecol Biogeogr 15:121-142

Bergstrom D, Chown SL (1999) Life at the front: history, ecology and change on southern ocean islands. Trends Ecol Evol 14:472-477

Bergstrom D, Selkirk P (1997) Distribution of bryophytes on subantarctic Heard Island. Bryology 100:349-355

Bergstrom DM, Selkirk PM (2007) Human impacts on sub-Antarctic terrestrial environments. Pap Proc R Soc Tasm 141:159-168

Bokhorst SF (2007) Functioning of terrestrial ecosystems of the maritime Antarctic in a warmer climate. Netherlands Institute of Ecology, Amsterdam

Breshears DD, Cobb NS, Rich PM, Price KP et al (2005) Regional vegetation die-off in response to global-change-type drought. Proc Natl Acad Sci USA 102:15144-15148

Carlquist S (1974) Island biology. Columbia University Press, New York

Chapuis JL, Boussès P, Barnaud G (1994) Alien mammals, impact and management in the French Subantarctic islands. Biol Conserv 67:97-104

Chevrier M, Vernon P, Frenot Y (1997) Potential effects of two alien insects on a sub-Antarctic wingless fly in the Kerguelen islands. In: Battaglia B, Valencia J, Walton DWH (eds) Antarctic communities: species, structure and survival. Cambridge University Press, Cambridge, pp 424-431

Chown SL (1990a) Possible effects of Quaternary climatic change on the composition of insect communities of the South Indian Ocean Province Islands. S Afr J Sci 86:386-391
Chown SL (1990b) Speciation in the sub-Antarctic weevil genus Dusmoecetes Jeannel (Coleoptera: Curculionidae). Syst Entomol 15:283-296

Chown SL (1994) Historical ecology of sub-Antarctic weevils (Coleoptera: Curculionidae): patterns and processes on isolated islands. J Nat Hist 28:411-433

Chown SL, Block W (1997) Comparative nutritional ecology of grass-feeding in a sub-Antarctic beetle: the impact of introduced species on Hydromedion sparsutum from South Georgia. Oecologia 111:216-224

Chown SL, Convey P (2006) Biogeography. In: Bergstrom DM, Convey P, Huiskes AHL (eds) Trends in Antarctic terrestrial and limnetic ecosystems. Springer, Dordrecht, pp 55-69

Chown SL, Convey P (2007) Spatial and temporal variability across life's hierarchies in the terrestrial Antarctic. Phil Trans R Soc Lond B 362:2307-2331

Chown SL, Language K (1994) Recently established Diptera and Lepidoptera on sub-Antarctic Marion Island. Afr Entomol 2:57-60

Chown SL, Smith VR (1993) Climate change and the short-term impact of feral house mice at the sub-Antarctic Prince Edward Islands. Oecologia 96:508-516

Chown SL, Gremmen NJM, Gaston KJ (1998) Ecological biogeography of Southern Ocean Islands: species-area relationships, human impacts, and conservation. Am Nat 152:562-575

Chown SL, Rodrigues ASL, Gremmen NJM, Gaston KJ (2001) World Heritage status and conservation of Southern Ocean Islands. Conserv Biol 15:550-557

Chown SL, McGeoch MA, Marshall DJ (2002) Diversity and conservation of invertebrates on the sub-Antarctic Prince Edward Islands. Afr Entomol 10:67-82

Chown SL, Sinclair BJ, Leinaas HP, Gaston KJ (2004) Hemispheric asymmetries in biodiversity - a serious matter for ecology. PLoS Biol 2:1701-1707

Chown SL, Hull B, Gaston KJ (2005) Human impacts, energy availability and invasion across Southern Ocean Islands. Glob Ecol Biogeogr 14:521-528

Chown SL, Davies S, Joubert L (2006) Prince Edward Islands environmental management plan version 0.1. Centre for Invasion Biology, Stellenbosch

Chown SL, Slabber S, McGeoch MA, Janion C, Leinaas HP (2007) Phenotypic plasticity mediates climate change responses among invasive and indigenous arthropods. Proc $\mathrm{R}$ Soc Lond $\mathrm{B}$ 274:2531-2537

Chown SL, Sinclair BJ, van Vuuren J (2008) DNA barcoding and the documentation of alien species establishment on sub-Antarctic Marion Island. Polar Biol, in press

Convey P (2006) Antarctic climate change and its influences on terrestrial ecosystems. In: Bergstrom DM, Convey P, Huiskes AHL (eds) Trends in Antarctic terrestrial and limnetic ecosystems. Springer, The Netherlands, pp 253-272

Convey P, Greenslade P, Arnold RJ, Block W (1999) Collembola of sub-Antarctic South Georgia. Polar Biol 22:1-6

Copson GR (1986) The diet of the introduced rodents Mus musculus L. and Rattus rattus L. on Subantarctic Macquarie Island. Aust J Wildl Res 133:441-445

Copson GR, Whinam J (1998) Response of vegetation on subantarctic Macquarie Island to reduced rabbit grazing. Aust J Bot 46:15-24

Crafford JE, Scholtz CH (1987) Quantitative differences between the insect faunas of sub-Antarctic Marion and Prince Edward Islands: a result of human intervention? Biol Conserv 40:255262

Crafford JE, Scholtz CH, Chown SL (1986) The insects of subAntarctic Marion and Prince Edward Islands; with a bibliography of entomology of the Kerguelen Biogeographical Province. S Afr J Antarct Res 16:41-84 
Craig DA (2003) Deconstructing Gondwana-words of warning from the Crozet Island Simuliidae (Diptera). Cimbebasia 19:157-164

Davies KF, Melbourne BA (1999) Statistical models of invertebrate distribution on Macquarie Island: a tool to assess climate change and local human impacts. Polar Biol 21:240-250

Davies SJ, Chown SL, Joubert LJ (2007) Renewed management system and provisions for South Africa's sub-Antarctic islands. Pap Proc R Soc Tasm 141:115-120

de Villiers MS, Cooper J, Carmichael N, Glass JP, Liddle GM, McIvor E, Micol T, Roberts A (2006) Conservation management at Southern Ocean Islands: towards the development of best practise guidelines. Polarforschung 75:113-131

Dingwall PR (ed) (1995) Progress in conservation of the Subantarctic Islands. IUCN, Gland

Easterling DR, Meehl GA, Parmesan C, Changnon SA, Karl TR, Mearns LO (2000) Climate extremes: observations, modeling, and impacts. Science 289:2068-2074

Ernsting G (1993) Observations on life cycle and feeding ecology of two recently introduced predatory beetle species at South Georgia, sub-Antarctic. Polar Biol 13:423-428

Ernsting G, van Ginkel W, Menken SBJ (1995a) Genetical population structure of Trechisibus antarcticus (Coleoptera; Carabidae) on South Georgia and on the Falkland islands. Polar Biol 15: 523-525

Ernsting G, Block W, MacAlister H, Todd C (1995b) The invasion of the carnivorous carabid beetle Trechisibus antarcticus on South Georgia (sub-Antarctic) and its effect on the endemic herbivorous beetle Hydromedion spasutum. Oecologia 103:34-42

Ernsting G, Brandjes GJ, Block W, Isaaks JA (1999) Life-history consequences of predation for a subantarctic beetle: evaluating the contribution of direct and indirect effects. J Anim Ecol 68:741-752

Evans KL, Warren PH, Gaston KJ (2004) Species-energy relationships at the macroecological scale: a review of the mechanisms. Biol Rev 79:1-25

Finizio A, Di Guardo A, Cartmale L (1998) Hazardous air pollutants (HAPs) and their effects on biodiversity: an overview of the atmospheric pathways of persistent organic pollutants (POPs) and suggestions for future studies. Environ Monit Assess 49:327-336

Frenot Y, Chown SL, Whinam J, Selkirk PM, Convey P, Skotnicki M, Bergstrom DM (2005) Biological invasions in the Antarctic: extent, impacts and implications. Biol Rev 80:45-72

Gabriel AGA, Chown SL, Barendse J, Marshall DJ, Mercer RD, Pugh PJA, Smith VR (2001) Biological invasions on Southern Ocean Islands: the Collembola of Marion Island as a test of generalities. Ecography 24:421-430

Gaston KJ (1992) Regional numbers of insect and plant species. Funct Ecol 6:243-247

Gaston KJ (2000) Global patterns in biodiversity. Nature 405:220227

Gaston KJ, Jones AG, Hänel C, Chown SL (2003) Rates of species introduction to a remote oceanic island. Proc R Soc Lond B 270:1091-1098

Greenslade P (2006) The invertebrates of Macquarie Island. Department of Environment and Heritage, Australian Antarctic Division, Kingston

Greenslade P, Melbourne BA, Davies KF, Stevens MI (2007a) The status of two exotic terrestrial Crustacea on sub-Antarctic Macquarie Island. Polar Rec 44:15-23

Greenslade P, Stevens MI, Edwards R (2007b) Invasion of two exotic flatworms to subantarctic Macquarie Island. Polar Biol 30: 961-967
Gremmen NJM (1981) The vegetation of the Subantarctic Islands Marion and Prince Edward. Dr. W. Junk, The Hague

Gremmen NJM, Smith VR (2008) Terrestrial vegetation and dynamics. In: Chown SL, Froneman PW (eds) The Prince Edward Islands. Land-sea interactions in a changing ecosystem. African Sun Media, in press

Gremmen NJM, Chown SL, Marshall DJ (1998) Impact of the introduced grass Agrostis stolonifera on vegetation and soil fauna communities at Marion Island, sub-Antarctic. Biol Conserv 85:223-231

Gressitt JL (1970) Subantarctic Entomology and Biogeography. Pacific Ins Monogr 23:295-374

Greve M, Gremmen NJM, Gaston KJ, Chown SL (2005) Nestedness of South Ocean island biotas: ecological perspectives on a biogeographical conundrum. J Biogeogr 32:155-168

Grobler GC, Janse van Rensburg L, Bastos ADS, Chimimba CT, Chown SL (2006) Molecular and morphometric assessment of the taxonomic status of Ectemnorhinus weevil species (Coleoptera: Curculionidae, Entiminae) from the sub-Antarctic Prince Edward Islands. J Zool Syst Evol Res 44:200-211

Hall K (2002) Review of present and Quaternary periglacial processes and landforms of the maritime and sub-Antarctic region. S Afr J Sci 98:71-81

Hänel C, Chown SL, Davies L (1998) Records of alien insect species from sub-Antarctic Marion and South Georgia Islands. Afr Entomol 6:366-369

Hänel C, Chown SL, Gaston KJ (2005) Gough Island. A natural history. African Sun Media, Stellenbosch

Hawkins BA, Pausas JG (2004) Does plant richness influence animal richness? the mammals of Catalonia (NE Spain). Divers Distrib 10:247-252

Hawkins BA, Porter EE (2003) Does herbivore diversity depend on plant diversity? The case of California butterflies. Am Nat 161:40-49

Hawkins BA, Field R, Cornell HV, Currie DJ, Guegan JF et al (2003) Energy, water, and broad-scale geographic patterns of species richness. Ecology 84:3105-3117

Hull BJ, Bergstrom DM (2006) Antarctic terrestrial and limnetic ecosystems conservation and management. In: Bergstrom DM, Convey P, Huiskes AHL (eds) Trends in Antarctic terrestrial and limnetic ecosystems. Springer, Dordrecht, pp 317-339

Hullé M, Pannetier D, Simon J-C, Vernon P, Frenot Y (2003) Aphids of sub-Antarctic Îles Crozet and Kerguelen: species diversity, host range and spatial distribution. Antarct Sci 15:203-209

Huyser O, Ryan PG, Cooper J (2000) Changes in population size, habitat use and breeding biology of lesser sheathbills (Chionis minor) at Marion Island: impacts of cats, mice and climate change? Biol Conserv 92:299-310

Jones AG, Chown SL, Ryan PG, Gremmen NJM, Gaston KJ (2003a) A review of conservation threats on Gough Island: a case study for terrestrial conservation in the Southern Oceans. Biol Conserv 113:75-87

Jones AG, Chown SL, Webb TJ, Gaston KJ (2003b) The free-living pterygote insects of Gough Island, South Atlantic Ocean. Syst Biodivers 1:213-273

Jones AG, Chown SL, Gaston KJ (2003c) Introduced house mice as a conservation concern on Gough Island. Biodivers Conserv 12:2107-2119

Kalmar A, Currie DJ (2006) A global model of island biogeography. Glob Ecol Biogeogr 15:72-81

Kennedy AD (1995) Antarctic terrestrial ecosystem response to global environmental change. Annu Rev Ecol Syst 26:683-704

Klok CJ, Chown SL (1997) Critical thermal limits, temperature tolerance and water balance of a sub-Antarctic caterpillar, 
Pringleophaga marioni (Lepidoptera: Tineidae). J Insect Physiol 43:685-694

Klok CJ, Chown SL (2003) Resistance to temperature extremes in sub-Antarctic weevils: interspecific variation, population differentiation and acclimation. Biol J Linn Soc 78:401-414

Lawton JH (2007) Ecology, politics and policy. J Appl Ecol 44:465-474

Lee JE, Chown SL (2007) Mytilus on the move: transport of an invasive bivalve to the Antarctic. Marine Ecol Prog Ser 339:307-310

Lee JE, Slabber S, Jansen van Vuuren B, van Noort S, Chown SL (2007) Colonisation of sub-Antarctic Marion Island by a nonindigenous aphid parasitoid Aphidius matricariae (Hymenoptera, Braconidae). Polar Biol 30:1195-1201

le Roux PC (2008) Climate and climate change. In: Chown SL, Froneman PW (eds) The Prince Edward Islands. Land-sea interactions in a changing ecosystem. African Sun Media, in press

le Roux PC, McGeoch MA (2007) Changes in climate extremes, variability and signature on sub-Antarctic Marion Island. Clim Change. doi: 10.1007/s10584-007-9259-y

Le Roux V, Chapuis J-L, Frenot Y, Vernon P (2002) Diet of the house mouse (Mus musculus) on Guillou Island, Kergeulen archipelago, Subantarctic. Polar Biol 25:49-57

le Roux PC, McGeoch MA, Nyakatya MJ, Chown SL (2005) Effects of a short-term climate change experiment on a sub-Antarctic keystone plant species. Glob Change Biol 11:1628-1639

Lewis PN, Hewitt CL, Riddle M, McMinn A (2003) Marine introductions in the Southern Ocean: an unrecognised hazard to biodiversity. Mar Pollut Bull 46:213-223

Lewis PN, Bergstrom DM, Whinam J (2006) Barging in: a temperate marine community travels to the subantarctic. Biol Invasions 8:787-795

Lewis-Smith RI, Walton DWH (1975) South Georgia sub-Antarctic. In: Rosswall T, Heal OW (eds) Structure and function of tundra ecosystems. Swedish Natural Science Research Council, Stockholm, pp 399-423

Lockwood JL, Cassey P, Blackburn TM (2005) The role of propagule pressure in explaining species invasions. Trends Ecol Evol 20:223-228

Lombard AT, Reyers B, Schonegevel LY, Cooper J, Smith-Adao LB et al (2007) Conserving pattern and process in the Southern Ocean: designing a marine protected area for the Prince Edward Islands. Antarct Sci 19:39-54

McGeoch MA, le Roux PC, Hugo EA, Chown SL (2006) Species and community responses to short-term climate manipulation: microarthropods in the sub-Antarctic. Aust Ecol 31:719-731

Millennium Ecosystem Assessment (2005) Ecosystems and human well-being: biodiversity synthesis. World Resources Institute, Washington

Muñoz J, Felicísimo AM, Cabezas F, Burgaz AR, Martínez I (2004) Wind as a long-distance dispersal vehicle in the Southern Hemisphere. Science 304:1144-1147

Myburgh M, Chown SL, Daniels SR, Jansen van Vuuren B (2007) Population structure, propagule pressure, and conservation biogeography in the sub-Antarctic: lessons from indigenous and invasive springtails. Divers Distrib 13:143-154

Novotný V, Drozd P, Miller SE, Kulfan M, Janda M, Basset Y, Weiblen GD (2006) Why are there so many species of herbivorous insects in tropical rainforests? Science 313:1115-1118

Peck LS, Convey P, Barnes DKA (2006) Environmental constraints on life histories in Antarctic ecosystems: tempos, timings and predictability. Biol Rev 81:75-109

Pugh PJA (1993) A synonymic catalogue of the Acari from Antarctica, the sub-Antarctic Islands and the Southern Ocean. J Nat Hist 27:323-421

Pugh PJA (2004) Biogeography of spiders (Araneae: Arachnida) on the islands of the Southern Ocean. J Nat Hist 38:1461-1487
Pugh PJA, Scott B (2002) Biodiversity and biogeography of nonmarine Mollusca on the islands of the Southern Ocean. J Nat Hist 36:927-952

Pugh PJA, Dartnall HJG, McInnes SJ (2002) The non-marine Crustacea of Antarctica and the islands of the Southern Ocean: biodiversity and biogeography. J Nat Hist 36:1047-1103

Pyšek P, Richardson DM, Rejmánek M, Webster GL, Williamson M, Kirschner J (2004) Alien plants in checklists and floras: towards better communication between taxonomists and ecologists. Taxon 53:131-143

Richardson DM, Pyšek P, Rejmánek M, Barbour MG, Panetta FD, West CJ (2000) Naturalization and invasion of alien plants: concepts and definitions. Divers Distrib 6:93-107

Scott JJ, Bergstrom DM (2006) Vegetation of Heard Island and the McDonald islands. In: Green K, Woehler E (eds) Heard Island: Southern Ocean Sentinel. Surrey Beatty and Sons, Chipping Norton, pp 69-90

Scott JJ, Kirkpatrick JB (2008) Rabbits, landslips and vegetation change on the coastal slopes of subantarctic Macquarie Island, 1980-2007: implications for management. Polar Biol, in press

Seebacher F, Davison W, Lowe CJ, Franklin CE (2005) A falsification of the thermal specialization paradigm: compensation for elevated temperatures in Antarctic fishes. Biol Lett $1: 151-154$

Selkirk PM, Seppelt RD, Selkirk DR (1990) The sub-Antarctic Macquarie Island: environment and biology. Cambridge University Press, Cambridge

Selmi S, Boulinier T (2001) Ecological biogeography of Southern Ocean Islands: the importance of considering spatial issues. Am Nat 158:426-437

Siemann E, Tilman D, Haarstad J, Richie M (1998) Experimental tests of the dependence of arthropod diversity on plant diversity. Am Nat 152:738-750

Sinclair BJ, Chown SL (2005) Deleterious effects of repeated cold exposure in a freeze-tolerant sub-Antarctic caterpillar. J Exp Biol 208:969-879

Sinclair BJ, Chown SL (2006) Catterpillars benefit from thermal ecosystem engineering by wandering albatrosses on sub-Antarctic Marion Island. Biol Lett 2:51-54

Slabber S, Chown SL (2002) The first record of a terrestrial crustacean, Porcellio scaber (Isopoda, Porcellionidae), from sub-Antarctic Marion Island. Polar Biol 25:855-858

Slabber S, Chown SL (2005) Differential responses of thermal tolerance to acclimation in the sub-Antarctic rove beetle Halmaeusa atriceps. Physiol Entomol 30:195-204

Slabber S, Worland MR, Leinaas HP, Chown SL (2007) Acclimation effects on thermal tolerances of springtails from sub-Antarctic Marion Island: indigenous and invasive species. J Insect Physiol 53:113-125

Smith VR (1992) Terrestrial slug recorded from sub-Antarctic Marion Island. J Mollusc Stud 58:80-81

Smith VR (2002) Climate change in the sub-Antarctic: an illustration from Marion Island. Clim Change 52:345-357

Smith VR (2007) Introduced slugs and indigenous caterpillars as facilitators of carbon and nutrient mineralisation on a subAntarctic island. Soil Biol Biochem 39:709-713

Smith VR, Froneman PW (2008) Nutrient dynamics in the vicinity of the Prince Edward Islands. In: Chown SL, Froneman PW (eds) The Prince Edward Islands. Land-sea interactions in a changing ecosystem. African Sun Media, in press

Smith VR, Steenkamp M (1990) Climatic change and its ecological implications at a subantarctic island. Oecologia 85:14-24

Smith VR, Steenkamp M (1992) Macroinvertebrates and litter nutrient release on a sub-Antarctic island. S Afr J Bot 58:105-116

Smith VR, Avenant NL, Chown SL (2002) The diet of house mice on a sub-Antarctic island. Polar Biol 25:703-715 
Stevens MI, Greenslade P, Hogg ID, Sunnucks P (2006) Southern Hemisphere springtails: could any have survived glaciation of Antarctica? Mol Biol Evol 23:874-882

Udvardy MDF (1987) The biogeographical realm Antarctica: a proposal. J R Soc N Z 17:187-194
Wace NM (1961) The vegetation of Gough Island. Ecol Monogr 31:337-367

Wallace PJ, Frey FA, Weis D, Coffin MF (2002) Origin and evolution of the Kerguelen Plateau, Broken Ridge and Kerguelen Archipelago: editorial. J Petrol 43:1105-1108 